\title{
Procedures Applied by Egyptian 5-star Hotels during the Coronavirus (COVID-19) Pandemic (Reality and Prospect)
}

Ahmed Rady*, M. Adel Atia

Faculty of Tourism and Hotels, Minia University, Egypt

\section{ARTICLE INFO}

Keywords:

COVID-19

Pandemic

Disinfection practices

Social Distancing Practices

Hurghada

Sharm El-Sheikh

\begin{abstract}
Coronavirus (Covid-19) pandemic is a highly contagious and pathogenic viral infection caused by severe acute respiratory syndrome. This pandemic has negatively affected all sectors of the world, especially the tourism sector. Therefore, this research aimed to study the procedures used in 5-star hotels to deal with this crisis and to analyze the gap between actual and targeted practices. A questionnaire was used as an instrument for collecting primary data that consisted of four dimensions; adjust hotel operations; food and beverage offers provided at the hotel; cleaning and disinfection practices; and social distancing practices. The sample of the research was selected using a convenience sampling technique from 5-star managers (49) and customers (155) at Hurghada and Sharm ElSheikh cities to select a sample of the research. The results revealed that there were statistically significant differences between the opinions of managers and customers in terms of all procedures applied at 5-star hotels during the coronavirus (COVID-19) pandemic. Moreover, there are significant differences between those procedures and the standard level. The research suggested that it is necessary to review the procedures followed by 5 -star hotels during COVID-19 pandemic such as adjusting hotel operations, food and beverages offers, cleaning and disinfection practices and social distancing practices.
\end{abstract}

(C2020 Faculty of Tourism and Hotels, Fayoum University All rights reserved

\section{Introduction}

Jennings, (2020) and Gossling et al. (2021) pointed out that the COVID-19 outbreak began in December 2019 in Wuhan, China. And it continued to spread in all countries of the world. Nearly 18 million cases of the virus have been recorded in all countries of the world. In addition, total casualties rose to more than eighteen million, and more than 719,000 people have died. Li et al., (2020) declared that when someone is infected with the COVID-19 virus, the initial symptoms usually appear for five to six days. The symptoms are represented in fever, cough, and shortness of breath (Sabbah, 2020). According to WHO reports. However, there are many individual cases in which the incubation period of the virus lasts for a long period of up to 40 days as the average incubation period for the virus is 14 days (Wang et al., 2020). The growth period for the virus may differ for severe cases from slight cases, and it depends on the patient's age and resistance (Abd El-Aziz and Stockanda, 2020).

\footnotetext{
* Corresponding author: email: ahmed.rady@ mu.edu.eg
} 


\section{Literature Review}

\subsection{The impact of the coronavirus on the global economy}

Nicola et al. (2020) stated that the World Health Organization (WHO) published that the spread of COVID-19 represents a global pandemic situation on January 30, 2020. Loeb, (2020) declared that governments imposed the closure of borders between them, the abolition of travel, and the imposition of quarantine in the countries that make up the largest economies of the world, and this raised fear of a huge economic crisis and an economic recession. In an effort by researchers to understand the impact of the virus on the economy, the researchers summarized the impact of COVID19 on the global economy, and their focus on the large sectors that include industries involved in extracting raw materials, and secondary sectors that participate in the production of final products and support sectors, including all service supply industries (Buck et al., 2020).

Fernandes (2020) agreed with Laing (2020) in that Covid-19 can destroy individual livelihoods, businesses of all kinds, industries, and entire economies, and this has led to a decrease in consumption by individuals and disruptions in production by factories and companies. In general, the work of global chains to supply purchases of various kinds was disrupted, which affected companies in all countries of the world. Thousands and millions of people will lose their jobs in the next few months. Also, many companies close operations, or announce layoffs. Also, consumers have changed their patterns of consumption and this has resulted in a dearth of goods in supermarkets in all countries of the world.

\subsection{The impact of the Coronavirus on the global tourism sector}

Lo, (2020) agreed with Maria et al., (2020) that many countries in the world are in lockdown, for an unknown period. Almost all individuals work from home, or not. People face travel bans, cancellations of important sporting events and bans on individual gatherings. Individuals do not use public transportation and avoid crowded public places, such as restaurants, malls, museums, and markets. Also, all sectors will be affected by this virus. Esposito, (2020) declared that the problems caused by the coronavirus are extremely bad in the hospitality-related sectors. The global travel industry - including airlines, cruise companies, casinos, restaurants, and hotels - is facing a decline of more than $90 \%$. Hoque et al. (2020) stated that tourist destinations have become deserted in all countries, airlines are working to reduce ground services and expel employees from them trade fairs and cruises have been canceled, also, hotels, restaurants, and casinos have closed all their activities. Bhattarai et al., (2020) showed that other companies depend on tourism and will suffer spillover effects. In addition to travel restrictions and quarantines, travel and tourism companies cancel travel and meetings, and governments closed borders between countries. The hotel and restaurant business during the spread of the coronavirus was affected mainly by the application of the "stay at home policy" announced by the governments of countries and the restrictions on the movement of individuals "social distancing between individuals" imposed by the government in many countries. This led to an abrupt closure in cities and villages to control the spread of the corona virus, which plunged many restaurants and hotels across the country into a sudden shock (larry, 2020). Hotels in all countries of the world canceled many billions of dollars of reservations, and the hotel sector tried to save 150 billion dollars. Ozili, (2019) confirmed that restaurant managers have laid off employees while their restaurants are temporarily closed. Also, many customers have stayed home, preferring to have home-cooked meals El-Erian, (2020) stated that some restaurant managers have criticized the government for its implementation of the stay-athome policy and the social distancing of individuals that has destroyed many restaurants and bars in cities. Add to that, governments announcing stayat-home or social distancing policies were an indirect way to inform individuals not to come to bars, hotels, restaurants, etc., which was a way to shatter the hospitality industry during the spread of the Coronavirus. Ozili and Arun, (2020) stated that many hotels in the United States, the United Kingdom, and some European countries announced their suspension of activities, which raised the number of lost jobs to 24.3 million jobs worldwide, and nearly 3.9 million in the United States alone due to the decrease in hotel occupancy during the outbreak of the coronavirus.

Youm7 Newspaper (2020), announced that tourism promotion authority in Egypt indicated that the tourism industry, like other economic sectors around the world, is now living through a difficult time due to this virus, as the total losses of the 
tourism sector since the virus began to appear so far have reached 12 billion US dollars, in addition to the losses of the aviation sector, which the international civil aviation Organization (ICAO) estimated at 5 billion EUR (5.5 billion USD) .

Akhbarelyom, (2020) reported that the economic advisor at the world tourism organization, dr. Saeed Al-Batouti, revealed the latest statistics and figures of the impact of the Corona virus on the tourism and travel industry in 2020. And Dr. Saeed Al- Batouti said that there is a loss of 850 million to 1.1 billion international tourists and a loss of 910 billion dollars to 1.2 trillion dollars in tourism revenues. Also, he added, an estimated decrease of 2.7 trillion USD in the gross domestic product for travel and tourism. Also, 100 to 120 million jobs in tourism are directly at risk.

\subsection{The impact of corona virus on Egypt tourism sector}

In Egypt, the Egyptian center for economic studies has signed that The Egyptian tourism sector has been affected by the outbreak of the Coronavirus, represented by a loss of $35 \%$ of tourism revenues estimated to be achieved in the Egyptian budget for the year 2019-2020, equivalent to $\$ 6$ billion (Alroeya, 2020) .

\subsection{Measures put in place by the government to operate hotels during the coronavirus pandemic.}

Alarabiya (2020) declared that on Sunday 20 May 2020, Egyptian Prime Minister Mostafa Madbouly approved some hotel accommodation controls in the country, under the guidelines of the World Health Organization to confront the Coronavirus as follows: prof. Khaled Al-Anani, Minister of Tourism, said that basic requirements have been approved for granting a health certificate to hotels, among which is the necessity for every hotel to provide a clinic and a doctor, in continuous coordination with the Ministry of Health in this regard, in addition to ensuring the quality of personal protective equipment and sterilization materials used, and not dealing only with companies approved by the Ministry of Health; The minister stated that the new requirements include forming joint work teams to pass through hotels and ensure that the requirements are met and ready for operation.

Alarabiya (2020) explained that dr. Khaled AlAnani said the conditions also require not to hold any parties or weddings inside the hotel, and to prohibit all kinds of nighttime activities in the hotel, with the allocation of a small hotel, or a floor in the hotel in every resort for quarantine for confirmed cases and suspected cases, while constantly continuing to conduct rapid testing of workers on Tourist city gates in coordination with the Ministry of Health. youm7, (2020), reported that regarding the requirements for guests, the Minister of Tourism confirmed that they include installing a sterilization device at the entrance to the hotel, ending the guest's check-in procedures electronically, or using single-use pens, sterilizing the guests' luggage before arriving at the hotel and leaving, and measuring the temperature of the guests upon entering the facility each time.

Also, Alborsaa news, (2020) added that the requirements also included the provision of hand sanitizer in the reception area and the various facilities, the regular disinfection of all public areas, the presence of accommodation for hotel workers, and the provision of isolation areas for the affected cases if they appeared. Also, the regulations for operating restaurants in hotels were reviewed, which include completely banning buffet service, relying on predetermined menus, prohibiting the serving of hookahs, measuring temperatures for restaurant visitors, leaving a distance of at least two meters between dining tables, and one meter between each person and another at the table, taking into account families with a maximum of 6 chairs at the large table, relying on single-use food utensils as possible, placing sterilizers and sterilizing wipes on every dining table, and developing educational instructions throughout the restaurant.

Akhbarelyom (2020) indicated that the requirements for internal supervision and laundry services were reviewed, which include disinfecting the rooms daily using the special tools of the vehicle to prevent the spread of infection, following the instructions of the Ministry of Health, and cleaning and sterilizing all physical points every hour in public places and public toilets using disinfectants decided by the Ministry of Health.

Guidance on Preparing Workplaces for COVID-19, (2020) reported that when selecting personal protective equipment consider factors such as purpose, appropriate, sanitization ability, removal, and cost. Also, when personal protective equipment will have to be used frequently for a long period of time, a more expensive and strong type of personal protective equipment may be less expensive overall than disposable the other. In addition, each manager should select the combination of personal 
protective equipment that guards' employees specific to their workplace.

Youm7 Newspaper (2020) and WHO (2020), declared that the egyptian federation of Tourist Chambers and the chamber of hotel establishments have prepared a vision and action plan for safe tourism operation by applying a package of precautionary measures, preventive and health measures, in hotels and tourist restaurants, to work in light of the continuing crisis of the new Corona virus, which establishments that wish to work during the current crisis are committed to safety of tourists and workers in the sector; The plan included seven main axes that hotel and tourism establishments must adhere to, from hosting the guest to his departure as follows: The first axis is the preventive measures and measures for the tourist and hotel establishments. The maximum number of hotel occupancy includes $25 \%$ of the hotel's capacity; as for the second axis, it includes prevention measures in hotels when receiving guests, which require the provision of a rapid test device and the value of the test, is charged to the guests' invoice. The hotel is committed to assigning a doctor to examine every guest, to ensure that everyone is free of any symptoms or respiratory diseases; The third axis concerns the prevention measures for internal supervision and the laundry, and includes disinfecting rooms on a daily basis with special tools to prevent the spread of infection and in accordance with the instructions of the Ministry of Health, cleaning and sterilizing all tangible points every hour in places and public bathrooms; The fourth axis is the prevention measures in the food and beverage department, which include leaving a distance of one and a half meters between the tables, the maximum number of chairs is four for each table, disinfecting the restaurant, tables and tools after every meal, and making sure that there are signs that do not touch the food by hand; As for the fifth axis, it is concerned with providing food and drinks in tourist restaurants, which also includes the same procedures inside hotel restaurants in addition to training all workers on safety tasks and procedures and wearing protective clothing; The sixth axis relates to preventive measures inside swimming pools and the beach. There is no conclusive evidence of infection transmission through swimming pools, health clubs, or water playgrounds, and maintenance and disinfection of swimming pools with chlorine nullify the Covid 19 virus; and the seventh and last axis concerns the gyms, which include cleaning up the physical points and all the corridors and changing the water of the Jacuzzi after each guest.

\section{Methodology}

To evaluate the procedures applied by 5-star hotels during the coronavirus (COVID-19) pandemic, a questionnaire was carried out covering sample of 5star hotel managers (49) and customers (155) at Hurghada and Sharm El-Sheikh cities as vital areas where the big presence of 5-star hotels in Egypt (Egypt hotels guide, 2016) to understand their perceptions of applying precautionary measures at these hotels. The questionnaire was divided into some of the main variables that were measured on a five-dimensional Likert scale to declare the attitude of the participants about the study variables. For content validity the survey was piloted on a sample of 48five-star hotels customers ( 28 customers at Hurghada hotels and 20 customers at Sharm El-Sheikh hotels). Then the questionnaires were modified according to participants' respondents. Data collected from a pilot study have been tabulated and analyzed using SPSS 25 statistical package.

\subsection{The sample of the research}

To determine the sample of the research, data collected from a pilot study have been analyzed using SPSS 25 statistical package as follows:

\section{Table 1}

Analyzing of the pilot study for customers of 5-star hotels data

\begin{tabular}{|c|c|c|c|}
\hline$\Sigma$ & $\mathrm{Z}$ & $\mathrm{e}$ & Levene's Sig. \\
\hline 0.317 & 1.96 & 0.05 & 0.058 \\
\hline
\end{tabular}

Table (1) indicated that Levene's coefficient is not significant $\mathrm{Sig}=0.058$. If the finding $\mathrm{p}$ value of Levene's test is more than 0.05 the obtained equal variances in groups are likely to have been collected based on random sampling from all the population with equal variances (Nodstokke and Zumbo, 2010). The researchers used Cochran's formula to determine the research sample size of customers as follow (Shkeeb, 2014):

$n=\frac{z^{2} \sigma^{2}}{e^{2}}$

Where: $\boldsymbol{\sigma}$ is standard deviation, $\mathbf{z}$ is standard degree, and $\mathbf{e}$ maximum allowed error

From the data showed in table 1 the researchers calculated a sample size for this research (customers' sample size), where the maximum 
allowed error (e) was 0.05 , this value is suitable for discrete data (Shkeeb, 2014), standard degree (z) was 1.96 and the standard deviation of the sample (б) was 0.317. Applying these values to Cochran's formula reveals that the suitable sample size for this research is 155 participants. A total of 170 questionnaire forms were distributed to guests at Hurghada and Sharm El-Sheikh cities (100 questionnaires distributed at Hurghada and 90 questionnaires distributed at Sharm El-Sheikh) only 158 guests positively shared the questionnaire (with a response rate of 93\%) this number exceed the appropriate sample size for this research. Moreover, the researchers applied Yamane's formula (Ajay and Mecah, 2014) to calculate managers' sample size as follow:

$\mathrm{n}=\mathrm{N} /(1+\mathrm{N} * \mathrm{e} 2)$

Where $\mathrm{n}$ : appropriate sample size, $\mathrm{N}$ : population size $=76$ five-star hotels (41hotels at Sharm-ElSheikh, 35 hotels at Hurghada (Egyptian hotel guide, 2016), e: Margin of error $=0.05$, this value is suitable for discrete data (Shkeeb, 2014).

Using the previous data, the appropriate size of the managers' sample size was 63 hotels' managers. The researchers distributed 65 questionnaires to five-star hotel managers at Hurghada and Sharm ElSheikh cities (30 questionnaires distributed at Hurghada and 35 questionnaires distributed at Sharm El-Sheikh) only 49 managers positively shared the questionnaire (with a response rate of $75.38 \%$ ) as shown in table 2.

\subsection{Questions of the Study}

What is the extent of adjusting hotel operations significance during the coronavirus (COVID-19) pandemic at 5-star hotels?

1. What is the significance of food and beverage offers provided at hotels during the coronavirus (COVID-19) pandemic at 5-star hotels?

2. What is the extent of cleaning and disinfection practices' significance during the coronavirus (COVID-19) pandemic at 5-star hotels?

3. What is the extent of social distancing practices' significance during the coronavirus (COVID-19) pandemic at 5-star hotels?

4. Are there significant differences between managers' and guests' awareness about procedures applied by 5-star hotels during the coronavirus (COVID-19) pandemic?

5. Are there significant differences between the tourist areas concerning procedures applied by hotels during the coronavirus (COVID-19) pandemic?

\subsection{Validity and Reliability}

A panel of experts in the field of hospitality management and group of health affaires experts were consulted to scale a content validity and to collect opinions and suggestions on the research tool. Prior to the main research, a pilot study was applied at a sample of the hotels under examination (40 customers and 10 managers at Hurghada and Sharm El-Sheikh cities) to test the questionnaire's content validity. Then the questionnaires were modified according to respondents' comments. Cronbach's Alpha coefficient was calculated (0.85) that exceeded 0.7 for all items; this means that all items are valid (Henson, 2001).

\subsection{Sample characteristic}

Table 2

Sample characteristic

\begin{tabular}{|l|l|c|c|c|c|c|}
\hline \multirow{2}{*}{ Variable } & \multicolumn{2}{|c|}{ Hurghada } & \multicolumn{2}{c|}{$\begin{array}{c}\text { Sharm } \\
\text { El-Sheikh }\end{array}$} & \multirow{2}{*}{$\begin{array}{c}\text { Average } \\
\text { percent }\end{array}$} \\
\cline { 3 - 7 } & & Freq & $\%$ & Freq & $\%$ & \\
\hline \multirow{2}{*}{$\begin{array}{l}\text { Sample } \\
\text { type }\end{array}$} & Managers & 25 & 23.8 & 24 & 24.2 & 24 \\
\hline \multirow{2}{*}{ Gender } & Customers & 80 & 76.2 & 75 & 75.8 & 76 \\
\cline { 2 - 7 } & Male & 102 & 97.1 & 97 & 98 & 97.5 \\
\hline \multirow{2}{*}{$\begin{array}{l}\text { Educational } \\
\text { background }\end{array}$} & $\begin{array}{l}\text { Intermediate } \\
\text { education }\end{array}$ & 16 & 15.2 & 15 & 15.1 & 15.15 \\
\cline { 2 - 6 } & $\begin{array}{l}\text { Higher } \\
\text { education }\end{array}$ & 76 & 72.3 & 72 & 72.7 & 72.5 \\
\cline { 2 - 6 } & Postgraduate & 13 & 12.5 & 12 & 12.2 & 12.35 \\
\hline
\end{tabular}

\section{Results and Discussions}

\subsection{Study variables analysis}

\subsubsection{Adjusting 5-star hotel operations.}

The purpose of this variable was to measure the level of procedures applied by 5-star hotels to adjust hotel operations during the coronavirus (COVID19) pandemic. The collected data is illustrated in tables (3-7):

\section{Table 3}

Factor analysis of adjusting hotel operations at 5-star hotels during the coronavirus (COVID-19) pandemic.

\begin{tabular}{|l|c|}
\hline \multicolumn{1}{|c|}{ Statements } & Loadings \\
\hline Working hours and daily service are restricted. & 0.762 \\
\hline Room service hours are reduced. & 0.872 \\
\hline The number of guests per room is reduced. & 0.847 \\
\hline $\begin{array}{l}\text { Upon the customer arrival, the hotel will provide } \\
\text { details of the changes in the services provided and } \\
\text { the improvements made to the cleaning policies. }\end{array}$ & 0.772 \\
\hline
\end{tabular}




\begin{tabular}{|l|c|}
\hline $\begin{array}{l}\text { The hotel and the customer are bound by the } \\
\text { updated laws and enforceable by the government. }\end{array}$ & 0.844 \\
\hline $\begin{array}{l}\text { Protocols are being intensified to clean public } \\
\text { areas and guest rooms. }\end{array}$ & 0.611 \\
\hline Sums of squared loadings & 0.784 \\
\hline
\end{tabular}

Factor analysis presented in table (3) attempted to determine essential factors that explain the pattern of associations within a set of observed variables. Extraction loading should not be less than 0.6 (Fabrigar, et al., 1999). Factor analysis suggested that all six elements were loaded on one factor explained $78.4 \%$ of the variation in the primary variable.

\section{Table 4}

Descriptive statistics for adjusting hotel operations at 5-star during the coronavirus (COVID-19) pandemic.

\begin{tabular}{|l|l|l|l|l|l|l|}
\hline \multirow{2}{*}{ The Axis } & \multicolumn{2}{|l|}{ Managers } & \multicolumn{2}{l|}{ customers } & \multicolumn{2}{l|}{ Rank } \\
\cline { 2 - 7 } & M. & SD. & M. & SD. & Mng. & Cust. \\
\hline PAHO*1 & 4.12 & 0.33 & 2.85 & 0.75 & 5 & 4 \\
\hline PAHO2 & 4.31 & 0.47 & 2.93 & 0.71 & 3 & 2 \\
\hline PAHO3 & 4.27 & 0.45 & 2.77 & 0.73 & 4 & 5 \\
\hline PAHO4 & 4.12 & 0.33 & 3.01 & 0.90 & 5 & 1 \\
\hline PAHO5 & 4.55 & 0.50 & 2.92 & 0.90 & 1 & 3 \\
\hline PAHO6 & 4.33 & 0.47 & 2.85 & 1.01 & 2 & 4 \\
\hline
\end{tabular}

*PAHO $=$ Procedure of Adjusting Hotel Operations

It can be concluded from the previous data tabulated in table 4 that according to managers' opinions, "The hotel and the customer are bound by the updated laws and enforceable by the government" was considered as one of the most important procedures applied by hotels during the coronavirus (COVID-19) pandemic by an average of 4.55; followed by "Protocols are being intensified to clean public areas and guest rooms" by an average of 4.33 of all the respondents." Room service hours are reduced "came in the third rank preference by the mean of 4.31 , then "The number of guests per room is reduced" came in the fourthorder preference by an average of 4.27 . This is followed by other procedures such as "Working hours and daily service are restricted" and" Upon the customer arrival, the hotel will provide details of the changes in the services provided and the improvements made to the cleaning policies" (see Table 4). On the other hand, according to customers' opinions, "Upon the customer arrival, the hotel will provide details of the changes in the services provided and the improvements made to the cleaning policies" was considered as one of the most important procedures applied by hotels during the coronavirus (COVID-19) pandemic by an average of 3.01; followed by " Room service hours are reduced "by mean of 2.93". The hotel and the customer are bound by the updated laws and enforceable by the government " came in the third rank preference by the average of 2.92; followed by "Protocols are being intensified to clean public areas and guest rooms" and "Working hours and daily service are restricted" by an average of 2.85 . This is followed by "The number of guests per room is reduced" by an average of 2.77. The differences between the opinions of managers and customers revealed that hospitality managers; especially in five-star hotels, should be fully aware of procedures of adjusting hotel operations applied during the coronavirus (COVID-19) pandemic to achieve customer satisfaction.

h.2. ${ }^{2}$ Comparison between managers and customers in terms of procedures of adjusting hotel operations applied during the coronavirus (COVID-19) pandemic.

This comparison is used to find out if there is a significant difference between managers' and customers' opinions in the five-star hotels in terms of the procedures of adjusting hotel operations applied during the coronavirus (COVID-19) pandemic. Furthermore, the Mann-Whitney U test was used to determine the differences between two groups (see Table 5).

\section{Table 5}

Differences between managers' and customers' opinions in the five-star hotels in terms of the procedures of adjusting hotel operations applied during the coronavirus (COVID-19) pandemic.

\begin{tabular}{|c|c|c|c|c|}
\hline procedures & $\begin{array}{l}\text { Sample } \\
\text { category }\end{array}$ & $\begin{array}{l}\text { Mean } \\
\text { rank } \\
\text { core } \\
\end{array}$ & $\begin{array}{l}\text { Mann- } \\
\text { Whitney } \\
\text { U test }\end{array}$ & $\begin{array}{l}\text { Asymp. } \\
\text { Sig. } \\
\text { (2tailed) }\end{array}$ \\
\hline \multirow[t]{2}{*}{$\mathrm{PAHO}^{*} 1$} & managers & 166.59 & \multirow[t]{2}{*}{656} & \multirow[t]{2}{*}{$0.000^{* * *}$} \\
\hline & customers & 82.24 & & \\
\hline \multirow[t]{2}{*}{ PAHO2 } & managers & 168.98 & \multirow[t]{2}{*}{540} & \multirow[t]{2}{*}{$0.000^{* *}$} \\
\hline & customers & 81.48 & & \\
\hline \multirow[t]{2}{*}{ PAHO3 } & managers & 170.08 & \multirow[t]{2}{*}{486} & \multirow[t]{2}{*}{$0.000^{* *}$} \\
\hline & customers & 81.14 & & \\
\hline \multirow[t]{2}{*}{ PAHO4 } & managers & 156.13 & \multirow[t]{2}{*}{1169} & \multirow[t]{2}{*}{$0.000^{* * *}$} \\
\hline & customers & 85.55 & & \\
\hline \multirow[t]{2}{*}{ PAHO5 } & managers & 166.92 & \multirow[t]{2}{*}{641} & \multirow[t]{2}{*}{$0.000^{* * *}$} \\
\hline & customers & 82.14 & & \\
\hline \multirow[t]{2}{*}{ PAHO6 } & managers & 159.70 & \multirow[t]{2}{*}{994} & \multirow[t]{2}{*}{$0.000^{* *}$} \\
\hline & customers & 84.42 & & \\
\hline
\end{tabular}

Table 5 showed that the Mann-Whitney U test revealed a significant difference between managers and customers in the five-star hotels in terms of all procedures of adjusting hotel operations applied during the coronavirus pandemic where sig. value for all procedures was less than 0.05 (see Table 5). 
Managers scored higher mean rank scores than customers in terms of all issues (see Table 5). This finding found that the views of both managers and consumers were differed, which confirms the managers' lack of commitment to procedures of adjusting hotel operations that reach consumer satisfaction. Therefore, it is necessary to review the procedures of adjusting hotel operations followed by the hotel managers during the coronavirus (COVID-19) pandemic periodically, to achieve customer satisfaction. This result answered the fifth question of this research.

To test the extent of adjusting hotel operations significance during the coronavirus pandemic at 5star hotels, the researchers applied the one-Sample T-test (with a test value of 5), this value was selected because it was a suitable value that referred to a level of "very agreement" (see Table 6).

\section{Table 6}

The extent of adjusting hotel operations significance during the coronavirus (COVID-19) pandemic at 5-star hotels.

\begin{tabular}{|l|l|l|l|l|}
\hline variable & T & Df & Test value & Sig. \\
\hline $\begin{array}{l}\text { adjusting hotel } \\
\text { operations }\end{array}$ & - & 203 & 5 & $0.000^{* * *}$ \\
\hline
\end{tabular}

** P-value $<0.01=$ Significant

From the previous results, the p-value was statistically significant results where the p-level was definitely less than .05 (so, the null hypothesis was rejected). There are significant differences between the procedures of adjusting hotel operations followed by the 5-star hotel managers during the coronavirus (COVID-19) and the standard level. This result agreed with the previous findings and answered the first question of this research. This finding suggested the importance of reviewing the procedures of adjusting hotel operations followed by 5 -star hotels during the coronavirus (COVID-19) pandemic. This result answered the first question of this research.

\subsection{Comparison between the tourist areas in terms} of procedures of adjusting hotel operations applied during the coronavirus (COVID-19) pandemic.

This comparison is used to find out if there is a significant difference between Hurghada and Sharm El-Sheikh cities in terms of the procedures of adjusting hotel operations applied during the coronavirus (COVID-19) pandemic. Furthermore, the Mann-Whitney U test was used to determine the differences between two groups (see Table 7).
Differences between Hurghada and Sharm El-Sheikh cities in terms of the procedures of adjusting hotel operations applied during the coronavirus (COVID-19) pandemic.

\begin{tabular}{|l|l|l|l|l|}
\hline procedures & $\begin{array}{l}\text { Sample } \\
\text { category }\end{array}$ & $\begin{array}{l}\text { Mean } \\
\text { rank } \\
\text { score }\end{array}$ & $\begin{array}{l}\text { Mann- } \\
\text { Whitney } \\
\text { U test }\end{array}$ & $\begin{array}{l}\text { Asymp. } \\
\text { Sig. } \\
\text { (2tailed) }\end{array}$ \\
\hline PAHO*1 & Hurghada & 100.31 & 4968 & 0.566 \\
\cline { 2 - 3 } & $\begin{array}{l}\text { Sharm El- } \\
\text { Sheikh }\end{array}$ & 104.82 & & \\
\hline PAHO2 & Hurghada & 100.31 & 4968 & 0.564 \\
\cline { 2 - 3 } & $\begin{array}{l}\text { Sharm El- } \\
\text { Sheikh }\end{array}$ & 104.82 & & \\
\hline PAHO3 & Hurghada & 102.44 & 5191 & 0.987 \\
\cline { 2 - 3 } & $\begin{array}{l}\text { Sharm El- } \\
\text { Sheikh }\end{array}$ & 102.57 & & \\
\hline PAHO4 & Hurghada & 100.02 & 4937.5 & 0.517 \\
\cline { 2 - 3 } & $\begin{array}{l}\text { Sharm El- } \\
\text { Sheikh }\end{array}$ & 105.13 & & \\
\hline PAHO5 & Hurghada & 100.82 & 5021 & 0.664 \\
\cline { 2 - 3 } & $\begin{array}{l}\text { Sharm El- } \\
\text { Sheikh }\end{array}$ & 104.28 & & \\
\hline PAHO6 & Hurghada & 100.53 & 4990.5 & 0.607 \\
\cline { 2 - 3 } & $\begin{array}{l}\text { Sharm El- } \\
\text { Sheikh }\end{array}$ & 104.59 & & \\
\hline
\end{tabular}

*PAHO = Procedure of Adjusting Hotel Operations

Table 7suggested that the Mann-Whitney U test revealed no significant difference between Hurghada and Sharm El-Sheikh five-star hotels in terms of all procedures of adjusting hotel operations applied during the coronavirus (COVID-19) pandemic where sig. value for all procedures was more than 0.05 (see Table 7). Meanwhile, the previous finding concluded the similarity in the practices applied at the five-star hotels in Hurghada and Sharm El-Sheikh cities during the coronavirus (COVID-19), which means that these procedures must be carefully monitored intensively. This result answers the sixth question of this research.

\subsection{Food and beverage's offer provided at 5-star hotels.}

The purpose of this variable was to measure the food and beverage offers provided at the hotel during the coronavirus (COVID-19) pandemic. The collected data is illustrated in tables (8-12):

\section{Table 8}

Factor analysis of food and beverage offers provided at 5-star hotels during the coronavirus pandemic.

\begin{tabular}{|l|l|}
\hline \multicolumn{1}{|c|}{ Statements } & Loadings \\
\hline $\begin{array}{l}\text { The hotel adheres to laws that are updated and } \\
\text { put in place by the government. }\end{array}$ & 0.857 \\
\hline The hotel introduces a variety of F\&B offers. & 0.790 \\
\hline $\begin{array}{l}\text { The hotel provides fixed meals to its } \\
\text { customers. }\end{array}$ & 0.842 \\
\hline
\end{tabular}

Table 7 


\begin{tabular}{|l|l|}
\hline $\begin{array}{l}\text { The hotel offers catering, events and banquet } \\
\text { services. }\end{array}$ & 0.937 \\
\hline The hotel offers beverage service in glasses. & 0.811 \\
\hline $\begin{array}{l}\text { The hotel also offers room service an option } \\
\text { for free delivery service to its guests to prevent } \\
\text { interaction with people. }\end{array}$ & 0.970 \\
\hline Sums of squared loadings & 0.867 \\
\hline
\end{tabular}

The previous table stated that all six elements were loaded on one factor explained $86.7 \%$ of the variation in the primary variable.

\section{Table 9}

Descriptive statistics for food and beverage's offers provided at 5-star hotels during the coronavirus pandemic.

\begin{tabular}{|l|l|l|l|l|l|l|}
\hline \multirow{2}{*}{ The Axis } & \multicolumn{2}{l|}{ managers } & \multicolumn{2}{l|}{ customers } & \multicolumn{2}{l|}{ Rank } \\
\cline { 2 - 7 } & M. & SD. & M. & SD. & Mng. & Cust. \\
\hline FBO*1 & 4.08 & 0.27 & 3.61 & 1.08 & 1 & 5 \\
\hline FBO2 & 4.16 & 0.37 & 4.37 & 1.05 & 2 & 3 \\
\hline FBO3 & 3.89 & 0.87 & 4.55 & 1.06 & 3 & 1 \\
\hline FBO4 & 3.36 & 1.2 & 4.49 & 1.09 & 6 & 2 \\
\hline FBO5 & 3.37 & 1.2 & 4.35 & 1.07 & 5 & 4 \\
\hline FBO6 & 3.83 & $\cdot .55$ & 3.03 & $.54 \cdot$ & 4 & 6 \\
\hline
\end{tabular}

*FBO = Food and Beverage Offer

From the previous table it can be shown that that according to managers' opinions, " The hotel adheres to laws that are updated and put in place by the government." was considered as one of the most important procedures applied by hotels during the coronavirus pandemic by an average of 4.08; followed by " The hotel introduces a variety of F\&B offers " by an average of 4.16 of all the respondents. "The hotel provides fixed meals to its customers "came in the third rank preference by the mean of 3.89 , then "The hotel also offers room service as an option for free delivery service to its guests to prevent interaction with people" came in the fourthorder preference by an average of 3.83 . This is followed by other procedures such as "The hotel offers beverage service in glasses "and" The hotel offers catering, events and banquet services" with averages of 3.37, 3.36 respectively (see Table 9). Contrariwise, according to customers' opinions," The hotel adheres to laws that are updated and put in place by the government " and " The hotel also offers room service an option for free delivery service to its guests in order to prevent interaction with people " were considered as the least important procedures applied by hotels during the coronavirus (COVID-19) pandemic by an average of 3.61 and 3.03 respectively (see Table 9). The differences between the opinions of managers and customers revealed that hospitality managers; especially in the five-star hotels, should be fully aware regarding the food and beverage offers provided during the coronavirus (COVID-19) pandemic in order to achieve customer satisfaction.

\subsection{Comparison between managers and customers} in terms of food and beverage offers provided at 5 star hotels during the coronavirus pandemic.

This comparison is used to find out if there is a significant difference between managers' and customers' opinions in the five-star hotels in terms of food and beverage offers provided at 5-star hotels during the coronavirus (COVID-19) pandemic. Furthermore, the Mann-Whitney U test was used to determine the differences between two groups (see Table 10).

Table 10

Differences between managers and customers' opinions in five-star hotels in terms of the food and beverage offers provided at 5-star hotels during the coronavirus pandemic.

\begin{tabular}{|l|l|l|l|l|}
\hline Procedures & $\begin{array}{l}\text { Sample } \\
\text { category }\end{array}$ & $\begin{array}{l}\text { Mean } \\
\text { rank } \\
\text { score }\end{array}$ & $\begin{array}{l}\text { Mann- } \\
\text { Whitney } \\
\text { U test }\end{array}$ & $\begin{array}{l}\text { Asymp. } \\
\text { Sig. } \\
\text { (2tailed) }\end{array}$ \\
\hline FBO $^{*} 1$ & Managers & 124.15 & 2736.5 & $0.002^{* *}$ \\
\cline { 2 - 3 } & Customers & 95.65 & & \\
\hline FBO2 & Managers & 75.55 & 2477 & $0.000^{* *}$ \\
\cline { 2 - 3 } & Customers & 111.02 & & \\
\hline \multirow{2}{*}{ FBO3 } & Managers & 59.38 & \multirow{2}{*}{1684.5} & $0.000^{* *}$ \\
\cline { 2 - 3 } & Customers & 116.13 & & \\
\hline FBO4 & Managers & 58.30 & \multirow{2}{*}{1631.5} & $0.000^{* *}$ \\
\cline { 2 - 3 } & Customers & 116.47 & & \\
\hline FBO5 & Managers & 63.87 & \multirow{2}{*}{1904.5} & $0.000^{* *}$ \\
\cline { 2 - 3 } & Customers & 114.71 & & \\
\hline FBO6 & Managers & 156.68 & 1142.5 & $0.000^{* *}$ \\
\cline { 2 - 3 } & Customers & 85.37 & & \\
\hline
\end{tabular}

$* \mathrm{FBO}=$ Food and Beverage Offer $* *$ P-value $<0.01=$ Significant

Table 10 showed that the Mann-Whitney U test revealed a significant difference between managers and customers in the five-star hotels in terms of all offers of food and beverages provided during the coronavirus (COVID-19) pandemic where sig. value for all procedures was less than 0.05 (see Table 10). Customers scored higher mean rank scores than managers in terms of all issues (see Table 10). This finding found that the views of both managers and consumers differed in favor of customers, which confirms the managers' interest in commitment to food and beverage offers during the coronavirus (COVID-19) pandemic that reach consumer satisfaction. Therefore, it is necessary to develop these offers and use them as a competitive advantage during the coronavirus. This result answers the fifth question of this research. 
To test the significance of food and beverage offers provided at hotels during the coronavirus (COVID19) pandemic at 5-star hotels, the researchers applied One-Sample T-test with test value of (see Table 11).

\section{Table 11}

The significance of food and beverage offers provided at hotels during the coronavirus (COVID-19) pandemic at the 5-star hotels.

\begin{tabular}{|l|l|l|l|l|}
\hline Variable & T & df & Test value & Sig. \\
\hline F\&B Offers & -21.53 & 203 & 5 & $0.000^{* *}$ \\
\hline
\end{tabular}

From the previous results, the p-value was statistically significant, where p-levels were less than .05 (so, the null hypothesis was rejected). In other word, there are significant differences between the level of food and beverage offers provided at 5-star hotels during the coronavirus (COVID-19) pandemic and the standard level. This result answered the second question of this research and suggested the importance of developing food and beverage offers provided at 5-star hotels during the coronavirus (COVID-19) pandemic.

4.6. Comparison between the tourist areas in terms of the food and beverage offers provided at the 5star hotels during the coronavirus (COVID-19) pandemic.

This comparison is used to find out if there is a significant difference between Hurghada and Sharm El-Sheikh cities in terms of the procedures of adjusting hotel operations applied during the coronavirus (COVID-19) pandemic. Furthermore, the Mann-Whitney U test was used to determine the differences between the two groups (see Table 12).

\section{Table 12}

Differences between Hurghada and Sharm El-Sheikh cities in terms of the food and beverage offers provided at the 5-star hotels during the coronavirus (COVID-19) pandemic.

\begin{tabular}{|l|l|l|l|l|}
\hline procedures & $\begin{array}{l}\text { Sample } \\
\text { category }\end{array}$ & $\begin{array}{l}\text { Mean } \\
\text { rank } \\
\text { score }\end{array}$ & $\begin{array}{l}\text { Mann- } \\
\text { Whitney } \\
\text { U test }\end{array}$ & $\begin{array}{l}\text { Asymp. } \\
\text { Sig. } \\
\text { (2tailed) }\end{array}$ \\
\hline FBO*1 & Hurghada & 102.40 & 5186.5 & 0.978 \\
\cline { 2 - 3 } & $\begin{array}{l}\text { Sharm El- } \\
\text { Sheikh }\end{array}$ & 102.61 & & \\
\hline FBO2 & Hurghada & 101.59 & 5102 & 0.798 \\
\cline { 2 - 3 } & $\begin{array}{l}\text { Sharm El- } \\
\text { Sheikh }\end{array}$ & 103.46 & & \\
\hline FBO3 & Hurghada & 100.72 & 5011 & 0.594 \\
\cline { 2 - 3 } & $\begin{array}{l}\text { Sharm El- } \\
\text { Sheikh }\end{array}$ & 104.38 & & \\
\hline FBO4 & Hurghada & 102.13 & 5158.5 & 0.913 \\
\hline
\end{tabular}

\begin{tabular}{|l|l|l|l|l|}
\hline & $\begin{array}{l}\text { Sharm El- } \\
\text { Sheikh }\end{array}$ & 102.89 & & \\
\hline \multirow{2}{*}{ FBO5 } & Hurghada & 104.66 & \multirow{2}{*}{4970.5} & 0.546 \\
\cline { 2 - 3 } & $\begin{array}{l}\text { Sharm El- } \\
\text { Sheikh }\end{array}$ & 100.21 & & \\
\hline FBO6 & Hurghada & 103.12 & 5132.5 & 0.863 \\
\cline { 2 - 3 } & $\begin{array}{l}\text { Sharm El- } \\
\text { Sheikh }\end{array}$ & 101.84 & & \\
\hline
\end{tabular}

$* \mathrm{FBO}=$ Food and Beverage Offer

The previous table determined that the MannWhitney $U$ test revealed no significant difference between Hurghada and Sharm El-Sheikh five-star hotels in terms of the food and beverage offers provided at 5-star hotels during the coronavirus (COVID-19) pandemic where sig. value for all offers was more than 0.05 (see Table 12). Meanwhile, the previous finding concluded the similarity in the offers provided at the five-star hotels in Hurghada and Sharm El-Sheikh cities during the coronavirus (COVID-19), which means that these offers must be carefully developed. This result was answered the sixth question of this research.

\subsection{Cleaning and disinfection practices}

The purpose of this variable was to analyze the cleaning and disinfection practices followed at the hotel during the coronavirus (COVID-19) pandemic. The collected data is illustrated in tables (13-17):

\section{Table 13}

Factor analysis of cleaning and disinfection practices followed at 5-star hotels during the coronavirus pandemic.

\begin{tabular}{|l|l|}
\hline \multicolumn{1}{|c|}{ Statements } & Loadings \\
\hline $\begin{array}{l}\text { The hotel is stepping up cleaning protocols for } \\
\text { its public areas and guest rooms. }\end{array}$ & .829 \\
\hline $\begin{array}{l}\text { Hotel staff wears personal protective } \\
\text { equipment, such as gloves, to protect them } \\
\text { from chemicals. }\end{array}$ & .836 \\
\hline $\begin{array}{l}\text { The hotel focuses on disinfecting doorknobs, } \\
\text { elevator buttons and phones to reduce the } \\
\text { spread of germs. }\end{array}$ & .801 \\
\hline $\begin{array}{l}\text { All hotel aides are trained in chemicals used in } \\
\text { rooms to ensure that room attendants and } \\
\text { public areas supervisors do their job. }\end{array}$ & .802 \\
\hline $\begin{array}{l}\text { The high traffic areas of the hotel are cleaned } \\
\text { every hour or two. }\end{array}$ & .820 \\
\hline $\begin{array}{l}\text { The hotel continues to provide alternatives to } \\
\text { towels and daily toiletries. }\end{array}$ & .812 \\
\hline $\begin{array}{l}\text { The hotel creates a personal cleaning note list } \\
\text { and a cleaning log chart for each area of the } \\
\text { hotel is placed on the back of the doors. }\end{array}$ & .874 \\
\hline $\begin{array}{l}\text { The main card is sterilized by front office } \\
\text { personnel as the keys are reused. }\end{array}$ & .853 \\
\hline
\end{tabular}




\begin{tabular}{|l|l|}
\hline $\begin{array}{l}\text { Make sure to wear gloves while sterilizing the } \\
\text { keys, so that germs do not spread to people or } \\
\text { other surfaces. }\end{array}$ & .747 \\
\hline $\begin{array}{l}\text { The hotel makes guests use a mobile phone and } \\
\text { check-in via mobile phone during their stay. }\end{array}$ & .725 \\
\hline $\begin{array}{l}\text { The hotel provides sterile wipes, a suitable } \\
\text { cleaning spray and paper towels everywhere in } \\
\text { the hotel. }\end{array}$ & .845 \\
\hline $\begin{array}{l}\text { The front office is cleaned when every guest } \\
\text { leaves. }\end{array}$ & .869 \\
\hline $\begin{array}{l}\text { Sterilizing stations are placed around the hotel, } \\
\text { so hotel staff make sure to check these stations } \\
\text { frequently if they need to be refilled. }\end{array}$ & .758 \\
\hline $\begin{array}{l}\text { The hotel ensures that hand sanitizer and soap } \\
\text { are available to its employees and customers in } \\
\text { prominent locations around the hotel. }\end{array}$ & .733 \\
\hline Sums of squared loadings & 0.807 \\
\hline
\end{tabular}

Factor analysis showed in the previous table suggested that all elements were loaded on one factor explained $80.7 \%$ of the variation in the primary variable.

\section{Table 14} Descriptive statistics for cleaning and disinfection praqticeserms of cleaning and disinfection practices followed at the 5-star hotels during the coronavirus (COVID-179) wed at the 5-star hotels during the coronavirus pandemic.

\begin{tabular}{|l|l|l|l|l|l|l|}
\hline \multirow{2}{*}{ The Axis } & \multicolumn{2}{l}{ managers } & \multicolumn{2}{l|}{ customers } & \multicolumn{2}{l|}{ Rank } \\
\cline { 2 - 7 } & M. & SD. & M. & SD. & Mng. & Cust. \\
\hline CDP1 & 4.08 & 0.40 & 2.90 & 0.69 & 5 & 1 \\
\hline CDP2 & 4.12 & 0.33 & 2.56 & 0.61 & 4 & 4 \\
\hline CDP3 & 4.12 & 0.33 & 2.76 & 0.81 & 4 & 3 \\
\hline CDP4 & 4.08 & 0.40 & 2.35 & 0.48 & 5 & 10 \\
\hline CDP5 & 4.12 & 0.33 & 2.24 & 0.50 & 4 & 12 \\
\hline CDP6 & 4.33 & 0.47 & 2.37 & 0.53 & 1 & 9 \\
\hline CDP7 & 4.33 & 0.47 & 2.30 & 0.51 & 1 & 11 \\
\hline CDP8 & 4.27 & 0.45 & 2.43 & 0.50 & 2 & 7 \\
\hline CDP9 & 4.18 & 0.39 & 2.39 & 0.57 & 3 & 8 \\
\hline CDP10 & 4.10 & 0.51 & 2.44 & 0.77 & 4 & 6 \\
\hline CDP11 & 4.12 & 0.33 & 2.43 & 0.66 & 4 & 7 \\
\hline CDP12 & 4.12 & 0.33 & 2.37 & 0.76 & 4 & 9 \\
\hline CDP13 & 4.12 & 0.33 & 2.52 & 0.80 & 4 & 5 \\
\hline CDP14 & 4.12 & 0.33 & 2.79 & 0.71 & 4 & 2 \\
\hline
\end{tabular}

$* \mathrm{CDP}=$ Cleaning and Disinfection Practice

It can be concluded from the previous table that according to managers' opinions, "The hotel continues to provide alternatives to towels and daily toiletries" as well as "The hotel creates a personal cleaning note list and a cleaning log chart for each area of the hotel is placed on the back of the doors" were considered as two of the most important cleaning and disinfection practices followed at the 5 -star hotels during the coronavirus pandemic by an average of 4.33; followed by " The main card is sterilized by front office personnel as the keys are reused "by an average of 4.27". Make sure to wear gloves while sterilizing the keys, so that germs do not spread to people or other surfaces", came in the third rank preference by the mean of 4.18 , This is followed by other practices such as "The hotel makes guests use a mobile phone and check-in via mobile phone during their stay" and "The hotel is stepping up cleaning protocols for its public areas and guest rooms"; which was the least important practices applied by 5 -star hotels (see table 14). On the other hand, according to customers' opinions "The hotel is stepping up cleaning protocols for its public areas and guest rooms "was considered as the most important procedures applied by 5-star hotels during the coronavirus (COVID-19) pandemic by an average of 2.9 (see Table 14). The differences between the opinions of managers and customers revealed that hospitality managers; especially in the five-star hotels, should be fully aware regarding the cleaning and disinfection practices followed during the coronavirus (COVID19) pandemic to achieve customer satisfaction.

(COVID-19) pandemic.

This comparison is used to find out if there is a significant difference between managers' and customers' opinions in the five-star hotels in terms of cleaning and disinfection practices followed at the 5-star hotels during the coronavirus (COVID19) pandemic. Furthermore, the Mann-Whitney U test was used to determine the differences between two groups (see table 15).

\section{Table 15}

Differences between managers and customers opinions in the five-star hotels in terms of cleaning and disinfection practices followed at the 5-star hotels during the coronavirus (COVID-19) pandemic.

\begin{tabular}{|l|l|l|l|l|}
\hline Procedures & $\begin{array}{l}\text { Sample } \\
\text { category }\end{array}$ & $\begin{array}{l}\text { Mean } \\
\text { rank } \\
\text { score }\end{array}$ & $\begin{array}{l}\text { Mann- } \\
\text { Whitney } \\
\text { U test }\end{array}$ & $\begin{array}{l}\text { Asymp. } \\
\text { Sig. } \\
\text { (2tailed) }\end{array}$ \\
\hline \multirow{2}{*}{ CDP*1 } & Managers & 166.54 & 659.5 & 0.000 \\
\cline { 2 - 3 } & Customers & 82.25 & & \\
\hline CDP2 & Managers & 175.61 & 215 & 0.000 \\
\cline { 2 - 3 } & Customers & 79.39 & & \\
\hline CDP3 & Managers & 163.77 & \multirow{2}{*}{795} & 0.000 \\
\cline { 2 - 3 } & Customers & 83.13 & & \\
\hline CDP4 & Managers & 178.88 & 55 & 0.000 \\
\cline { 2 - 3 } & Customers & 78.35 & & \\
\hline CDP5 & Managers & 177.81 & \multirow{2}{*}{107.5} & 0.000 \\
\cline { 2 - 3 } & Customers & 78.69 & & \\
\hline CDP6 & Managers & 178.65 & 66 & 0.000 \\
\cline { 2 - 3 } & Customers & 78.43 & & \\
\hline CDP7 & Managers & 178.65 & 66 & 0.000 \\
\cline { 2 - 3 } & Customers & 78.43 & & \\
\hline CDP8 & Managers & 180.00 & 0.000 & 0.000 \\
\hline
\end{tabular}




\begin{tabular}{|l|l|l|l|l|}
\hline & Customers & 78.00 & & \\
\hline CDP9 & Managers & 177.14 & 140 & 0.000 \\
\cline { 2 - 3 } & Customers & 78.9 & & \\
\hline \multirow{2}{*}{ CDP10 } & Managers & 168.89 & 544.5 & 0.000 \\
\cline { 2 - 3 } & Customers & 81.51 & & \\
\hline CDP11 & Managers & 175.31 & 230 & 0.000 \\
\cline { 2 - 3 } & Customers & 79.48 & & \\
\hline CDP12 & Managers & 171.22 & 430 & 0.000 \\
\cline { 2 - 3 } & Customers & 80.77 & & \\
\hline CDP13 & Managers & 168.72 & 552 & 0.000 \\
\cline { 2 - 3 } & Customers & 81.56 & & \\
\hline \multirow{2}{*}{ CDP14 } & Managers & 168.59 & 559 & 0.000 \\
\cline { 2 - 3 } & Customers & 81.61 & & \\
\hline
\end{tabular}

$* * \mathrm{CDP}=$ Cleaning and Disinfection Practice, $* *$ P-value < $0.01=$ Significant

Table 15 showed that the Mann-Whitney U test revealed a significant difference between managers and customers in the five-star hotels in terms of all cleaning and disinfection practices followed at the 5-star hotels during the coronavirus (COVID-19) pandemic where sig. value for all practices was less than 0.05 (see Table 15). Managers scored higher mean rank scores than customers in terms of all practices (see Table 15). This finding found that the views of both managers and consumers differed in favor of managers, which confirms the managers' lack of commitment to practices that reach consumer satisfaction. Therefore, it is necessary to review the cleaning and disinfection practices followed by 5-star hotel managers during the coronavirus (COVID-19) periodically to achieve customer satisfaction. This result answers the $5^{\text {th }}$ question of this research.

To test the significance of cleaning and disinfection practices followedby 5-star hotels during the coronavirus (COVID-19) followed by 5 -star hotels, the researchers applied One-Sample T-test; with a test value of 5 (see Table 16).

\section{Table 16}

Level of cleaning and disinfection practices followed by 5-star hotels during the coronavirus (COVID-19) followed by 5 -star hotels.

\begin{tabular}{|l|l|l|l|l|}
\hline Variable & $\mathrm{T}$ & Df & $\begin{array}{l}\text { Test } \\
\text { value }\end{array}$ & Sig. \\
\hline $\begin{array}{l}\text { cleaning and } \\
\text { disinfection } \\
\text { practices }\end{array}$ & -40.02 & 203 & 5 & $0.000^{* *}$ \\
\hline
\end{tabular}

** $\mathrm{P}$-value $<0.01=$ Significant

As shown in table 16, the p-value was statistically significant, where the p-level was less than .05 (so, the null hypothesis was rejected). In the other word, there are significant differences between the level of cleaning and disinfection practices followed by 5-star hotels during the coronavirus (COVID-19) pandemic and the standard level. This finding answered the third question of this research and suggested the importance of reviewing the cleaning and disinfection practices followed by 5-star hotels during the coronavirus (COVID-19) pandemic.

4.9. Comparison between the tourist areas in terms of cleaning and disinfection practices followed at the 5-star hotels during the coronavirus (COVID19) pandemic

This comparison is used to find out if there is a significant difference between Hurghada and Sharm El-Sheikh cities in terms of cleaning and disinfection practices followed at the 5-star hotels during the coronavirus (COVID-19) pandemic. Furthermore, the Mann-Whitney U test was used to determine the differences between two groups (see Table 17).

\section{Table 17}

Differences between Hurghada and Sharm El-Sheikh cities in terms of cleaning and disinfection practices followed at the 5-star hotels during the coronavirus (COVID-19) pandemic.

\begin{tabular}{|c|c|c|c|c|}
\hline Procedures & $\begin{array}{l}\text { Sample } \\
\text { category }\end{array}$ & $\begin{array}{l}\text { Mean } \\
\text { rank } \\
\text { score }\end{array}$ & $\begin{array}{l}\text { Mann- } \\
\text { Whitney } \\
\text { U test }\end{array}$ & $\begin{array}{l}\text { Asymp. } \\
\text { Sig. } \\
\text { (2tailed) }\end{array}$ \\
\hline \multirow[t]{2}{*}{$\mathrm{CDP}^{*} 1$} & Hurghada & 101.06 & \multirow[t]{2}{*}{5046.5} & \multirow[t]{2}{*}{0.7} \\
\hline & $\begin{array}{l}\text { Sharm El- } \\
\text { Sheikh }\end{array}$ & 104.03 & & \\
\hline \multirow[t]{2}{*}{ CDP2 } & Hurghada & 100.99 & \multirow[t]{2}{*}{5038.5} & \multirow[t]{2}{*}{0.68} \\
\hline & $\begin{array}{l}\text { Sharm El- } \\
\text { Sheikh }\end{array}$ & 104.11 & & \\
\hline \multirow[t]{2}{*}{ CDP3 } & Hurghada & 101.82 & \multirow[t]{2}{*}{5126.5} & \multirow[t]{2}{*}{0.85} \\
\hline & $\begin{array}{l}\text { Sharm El- } \\
\text { Sheikh }\end{array}$ & 103.22 & & \\
\hline \multirow[t]{2}{*}{ CDP4 } & Hurghada & 102.28 & \multirow[t]{2}{*}{5174} & \multirow[t]{2}{*}{0.95} \\
\hline & $\begin{array}{l}\text { Sharm El- } \\
\text { Sheikh }\end{array}$ & 102.74 & & \\
\hline \multirow[t]{2}{*}{ CDP5 } & Hurghada & 104.91 & \multirow[t]{2}{*}{4944} & \multirow[t]{2}{*}{0.49} \\
\hline & $\begin{array}{l}\text { Sharm El- } \\
\text { Sheikh }\end{array}$ & 99.94 & & \\
\hline \multirow[t]{2}{*}{ CDP6 } & Hurghada & 99.81 & \multirow[t]{2}{*}{4915} & \multirow[t]{2}{*}{0.46} \\
\hline & $\begin{array}{l}\text { Sharm El- } \\
\text { Sheikh }\end{array}$ & 105.35 & & \\
\hline \multirow[t]{2}{*}{ CDP7 } & Hurghada & 100.30 & \multirow[t]{2}{*}{4966.5} & \multirow[t]{2}{*}{0.54} \\
\hline & $\begin{array}{l}\text { Sharm El- } \\
\text { Sheikh }\end{array}$ & 104.83 & & \\
\hline \multirow[t]{2}{*}{ CDP8 } & Hurghada & 102.09 & \multirow[t]{2}{*}{5154.5} & \multirow[t]{2}{*}{0.91} \\
\hline & $\begin{array}{l}\text { Sharm El- } \\
\text { Sheikh }\end{array}$ & 102.93 & & \\
\hline \multirow[t]{2}{*}{ CDP9 } & Hurghada & 102.59 & \multirow[t]{2}{*}{5188.5} & \multirow[t]{2}{*}{0.98} \\
\hline & $\begin{array}{l}\text { Sharm El- } \\
\text { Sheikh }\end{array}$ & 102.41 & & \\
\hline \multirow[t]{2}{*}{ CDP10 } & Hurghada & 102.16 & \multirow[t]{2}{*}{5162} & \multirow[t]{2}{*}{0.92} \\
\hline & $\begin{array}{l}\text { Sharm El- } \\
\text { Sheikh }\end{array}$ & 102.86 & & \\
\hline
\end{tabular}




\begin{tabular}{|l|l|l|l|l|}
\hline CDP11 & Hurghada & 102.65 & 5182 & 0.96 \\
\cline { 2 - 3 } & $\begin{array}{l}\text { Sharm El- } \\
\text { Sheikh }\end{array}$ & 102.34 & & \\
\hline CDP12 & Hurghada & 101.44 & 5086 & 0.77 \\
\cline { 2 - 3 } & $\begin{array}{l}\text { Sharm El- } \\
\text { Sheikh }\end{array}$ & 103.63 & & \\
\hline CDP13 & Hurghada & 101.07 & 5047 & 0.70 \\
\cline { 2 - 3 } & $\begin{array}{l}\text { Sharm El- } \\
\text { Sheikh }\end{array}$ & 104.02 & & \\
\hline CDP14 & Hurghada & 100.08 & 4943.5 & 0.52 \\
\cline { 2 - 3 } & $\begin{array}{l}\text { Sharm El- } \\
\text { Sheikh }\end{array}$ & 105.07 & & \\
\hline
\end{tabular}

$* * \mathrm{CDP}=$ Cleaning and Disinfection Practice

The previous table determined that the MannWhitney $U$ test revealed no significant difference between Hurghada and Sharm El-Sheikh five-star hotels in terms of cleaning and disinfection practices followed at the 5-star hotels during the coronavirus (COVID-19) pandemic, where sig. value for all practices was more than 0.05 (see Table 17). Meanwhile, the previous finding concluded the similarity in the practices followed at the five-star hotels in Hurghada and Sharm ElSheikh cities during the coronavirus (COVID-19). This result was answered the sixth question of this research.

\subsection{Social distancing practices}

The purpose of this variable was to analyze the social distancing practices followed at the 5-star hotels during the coronavirus (COVID-19) pandemic. The collected data is illustrated in tables $(18-22)$ :

\section{Table 18}

Factor analysis of social distancing practices followed at the 5-star hotels during the coronavirus (COVID-19) pandemic

\begin{tabular}{|l|l|}
\hline \multicolumn{1}{|c|}{ Statements } & Loadings \\
\hline $\begin{array}{l}\text { The hotel creates a barrier at the reception to } \\
\text { keep a distance between employee and } \\
\text { customer. }\end{array}$ & 0.847 \\
\hline $\begin{array}{l}\text { Place key cards for guests at the front office } \\
\text { instead of handing them to the customer hand } \\
\text { in hand. }\end{array}$ & 0.857 \\
\hline $\begin{array}{l}\text { The hotel prevents large groups from gathering } \\
\text { in the lobby and near the elevators. }\end{array}$ & 0.788 \\
\hline $\begin{array}{l}\text { The hotel posts signs to guests that the } \\
\text { elevators are not congested and wait for the } \\
\text { next elevator so everyone can practice social } \\
\text { distancing. }\end{array}$ & 0.771 \\
\hline $\begin{array}{l}\text { The hotel operates social distancing lines and } \\
\text { identifies a way to distance standing people by } \\
\text { placing signs at six feet, the lines can be taut } \\
\text { with signs or small cones on the ground. }\end{array}$ & 0.687 \\
\hline $\begin{array}{l}\text { The hotel offers printouts to its guests of the } \\
\text { various in-room exercises that they can do } \\
\text { since the fitness center is closed. }\end{array}$ & 0.909 \\
\hline
\end{tabular}

\begin{tabular}{|l|l|}
\hline $\begin{array}{l}\text { If the hotel detects a guest or employee } \\
\text { infected with the COVID-19, the hotel contacts }\end{array}$ & 0.852 \\
the local health department and follows the \\
cleaning procedures for the guest room.
\end{tabular}

The previous table showed that all loading coefficients for all practices were exceeded 0.6 except the last practice (see table 18 ) with a loading coefficient of 0.465 , so the researchers deleted this sentence from the data analysis (Fabrigar, et al., 1999).

\section{Table 19}

Descriptive statistics for social distancing practices followed at the 5-star hotels during the coronavirus (COVID-19) pandemic

\begin{tabular}{|l|l|l|l|l|l|l|}
\hline \multirow{2}{*}{ The Axis } & \multicolumn{2}{|l|}{ managers } & \multicolumn{2}{l|}{ Customers } & \multicolumn{2}{l|}{ Rank } \\
\cline { 2 - 7 } & M. & SD. & M. & SD. & Mng. & Cust. \\
\hline SDP*1 & 4.18 & 0.39 & 2.32 & 0.47 & 2 & 6 \\
\hline SDP2 & 4.10 & 0.51 & 2.23 & 0.49 & 4 & 7 \\
\hline SDP3 & 4.04 & 0.45 & 2.35 & 0.66 & 5 & 4 \\
\hline SDP4 & 4.12 & 0.33 & 2.45 & 0.70 & 3 & 2 \\
\hline SDP5 & 4.12 & 0.33 & 2.61 & 0.79 & 3 & 1 \\
\hline SDP6 & 4.12 & 0.33 & 2.18 & 0.46 & 3 & 8 \\
\hline SDP7 & 4.12 & 0.33 & 2.34 & 0.57 & 3 & 5 \\
\hline SDP8 & 4.20 & 0.41 & 2.43 & 0.68 & 1 & 3 \\
\hline
\end{tabular}

*SDP $=$ Social Distancing Practices

The previous table indicated that according to managers' opinions, " The hotel tracks the contacts of the injured person, and then traces the guest to link the contact during the time of the customer's stay "was considered as the more important procedures applied by 5-star hotels during the coronavirus (COVID-19) pandemic by an average of 4.20 , followed by " The hotel creates a barrier at the reception to keep distance between employee and customer " by an average of 4.18. This was followed by other practices (see table 19). On the other hand, according to customers' opinions "The hotel operates social distancing lines and identifies a way to distance standing people by placing signs at six feet, the lines can be taut with signs or small cones on the ground" was considered as the more important procedures applied by 5-star hotels during the coronavirus (COVID-19) pandemic by an average of 2.61 , followed by " The hotel posts signs to guests that the elevators are not congested and wait for the next elevator so everyone can practice social distancing "by an average of 2.45 This was followed by other practices (see table 19). 
The differences between the opinions of managers and customers revealed that hospitality managers; especially in five-star hotels, should be fully emphasize that customers are aware of the importance of social distancing practices during the coronavirus (COVID-19) pandemic.

\subsection{Comparison between managers and customers} in terms of social distancing practices followed at the 5-star hotels during the coronavirus (COVID19) pandemic.

This comparison is used to find out if there is a significant difference between managers' and customers' opinions in the five-star hotels in terms of social distancing practices followed at the 5-star hotels during the coronavirus (COVID-19) pandemic. Furthermore, the Mann-Whitney U test was used to determine the differences between the two groups (see Table 20).

\section{Table 20}

Differences between managers' and customers' opinions in the five-star hotels in terms of social distancing practices followed at the 5-star hotels during the coronavirus (COVID-19) pandemic.

\begin{tabular}{|l|l|l|l|l|}
\hline Procedures & $\begin{array}{l}\text { Sample } \\
\text { category }\end{array}$ & $\begin{array}{l}\text { Mean } \\
\text { rank } \\
\text { score }\end{array}$ & $\begin{array}{l}\text { Mann- } \\
\text { Whitney } \\
\text { U test }\end{array}$ & $\begin{array}{l}\text { Asymp. } \\
\text { Sig. } \\
\text { (2tailed) }\end{array}$ \\
\hline \multirow{2}{*}{ SDP*1 } & Managers & 180.00 & 174 & 0.000 \\
\cline { 2 - 3 } & Customers & 78.00 & & \\
\hline SDP2 & Managers & 176.69 & \multirow{2}{*}{162} & 0.000 \\
\cline { 2 - 3 } & Customers & 79.05 & & \\
\hline SDP3 & Managers & 171.39 & \multirow{2}{*}{422} & 0.000 \\
\cline { 2 - 3 } & Customers & 80.72 & & \\
\hline \multirow{2}{*}{ SDP4 } & Managers & 171.66 & \multirow{2}{*}{408.5} & 0.000 \\
\cline { 2 - 3 } & Customers & 80.64 & & \\
\hline \multirow{2}{*}{ SDP5 } & Managers & 166.84 & \multirow{2}{*}{645} & 0.000 \\
\cline { 2 - 3 } & Customers & 82.16 & & \\
\hline SDP6 & Managers & 177.81 & \multirow{2}{*}{107.5} & 0.000 \\
\cline { 2 - 3 } & Customers & 78.69 & & \\
\hline SDP7 & Managers & 176.49 & \multirow{2}{*}{172} & 0.000 \\
\cline { 2 - 3 } & Customers & 79.11 & & \\
\hline SDP8 & Managers & 174.42 & 273 & 0.000 \\
\cline { 2 - 3 } & Customers & 79.76 & & \\
\hline
\end{tabular}

$*$ SDP $=$ social distancing practices $* *$ P-value $<0.01=$ Significant

Table 20 showed that the Mann-Whitney $U$ test revealed significant difference between managers and customers in the five-star hotels in terms of all social distancing practices followed at the 5-star hotels during the coronavirus (COVID-19) pandemic where sig. value for all practices was less than 0.05. Managers scored higher mean rank scores than customers in terms of all practices (see Table 20). This finding found that the views of both managers and consumers differed in favor of managers, which confirms the managers' lack of commitment to practices that reach consumer satisfaction. Therefore, it is necessary to emphasize the importance of social distancing practices followed by 5-star hotel managers during the coronavirus (COVID-19) significantly in order to achieve customer satisfaction. This result answers the fifth question of this research.

To test the significance of social distancing practices followed by 5 -star hotels during the coronavirus (COVID-19) followed by 5 -star hotels, the researchers applied a One-Sample T-test; with a test value of 5 (see Table 21).

\section{Table 21}

Level of social distancing practices followed by 5-star hotels during the coronavirus (COVID-19) followed by 5-star hotels.

\begin{tabular}{|l|l|l|l|l|}
\hline Variable & $\mathrm{T}$ & $\mathrm{df}$ & $\begin{array}{l}\text { Test } \\
\text { value }\end{array}$ & Sig. \\
\hline $\begin{array}{l}\text { social distancing } \\
\text { practices }\end{array}$ & -37.6 & 203 & 5 & $0.000^{* *}$ \\
\hline
\end{tabular}

As shown in table 21 , the p-value was statistically significant, where the p-level was definitely less than .05 (so, the null hypothesis was rejected). There are significant differences between the level of social distancing practices followed by 5 -star hotels during the coronavirus (COVID-19) pandemic and the standard level. This result answered the fourth question of this research and suggested the importance of applying the social distancing 5-star hotels during the coronavirus (COVID-19) pandemic.

\subsection{Comparison between tourist areas in terms of social distancing practices followed at the 5-star hotels during the coronavirus (COVID-19) pandemic.}

This comparison is used to find out if there is a significant difference between Hurghada and Sharm El-Sheikh cities in terms of social distancing practices followed at the 5-star hotels during the coronavirus (COVID-19) pandemic. Furthermore, the Mann-Whitney U test was used to determine the differences between the two groups (see Table 22).

Table 22

Differences between Hurghada and Sharm El-Sheikh cities in terms of social distancing practices followed at 5-star hotels during the coronavirus pandemic.

\begin{tabular}{|l|l|l|l|l|}
\hline procedures & $\begin{array}{l}\text { Sample } \\
\text { category }\end{array}$ & $\begin{array}{l}\text { Mean } \\
\text { rank } \\
\text { score }\end{array}$ & $\begin{array}{l}\text { Mann- } \\
\text { Whitney } \\
\text { U test }\end{array}$ & $\begin{array}{l}\text { Asymp. } \\
\text { Sig. } \\
\text { (2tailed) }\end{array}$ \\
\hline SDP*1 1 & Hurghada & 101.43 & 5085 & 0.771 \\
\hline
\end{tabular}




\begin{tabular}{|c|c|c|c|c|}
\hline & $\begin{array}{l}\text { Sharm El- } \\
\text { Sheikh }\end{array}$ & 103.64 & & \\
\hline \multirow[t]{2}{*}{ SDP2 } & Hurghada & 101.48 & \multirow[t]{2}{*}{5090} & \multirow[t]{2}{*}{0.770} \\
\hline & $\begin{array}{l}\text { Sharm El- } \\
\text { Sheikh }\end{array}$ & 103.59 & & \\
\hline \multirow[t]{2}{*}{ SDP3 } & Hurghada & 101.05 & \multirow[t]{2}{*}{5045} & \multirow[t]{2}{*}{0.685} \\
\hline & $\begin{array}{l}\text { Sharm El- } \\
\text { Sheikh }\end{array}$ & 104.04 & & \\
\hline \multirow[t]{2}{*}{ SDP4 } & Hurghada & 99.02 & \multirow[t]{2}{*}{4832.5} & \multirow[t]{2}{*}{0.342} \\
\hline & $\begin{array}{l}\text { Sharm El- } \\
\text { Sheikh }\end{array}$ & 106.19 & & \\
\hline \multirow[t]{2}{*}{ SDP5 } & Hurghada & 98.63 & \multirow[t]{2}{*}{4791.5} & \multirow[t]{2}{*}{0.299} \\
\hline & $\begin{array}{l}\text { Sharm El- } \\
\text { Sheikh }\end{array}$ & 106.60 & & \\
\hline \multirow[t]{2}{*}{ SDP6 } & Hurghada & 101.47 & \multirow[t]{2}{*}{5089.5} & \multirow[t]{2}{*}{0.762} \\
\hline & $\begin{array}{l}\text { Sharm El- } \\
\text { Sheikh }\end{array}$ & 103.59 & & \\
\hline \multirow[t]{2}{*}{ SDP7 } & Hurghada & 101.79 & \multirow[t]{2}{*}{5122.5} & \multirow[t]{2}{*}{0.844} \\
\hline & $\begin{array}{l}\text { Sharm El- } \\
\text { Sheikh }\end{array}$ & 103.26 & & \\
\hline \multirow[t]{2}{*}{ SDP8 } & Hurghada & 103.19 & \multirow[t]{2}{*}{5125} & \multirow[t]{2}{*}{0.853} \\
\hline & $\begin{array}{l}\text { Sharm El- } \\
\text { Sheikh }\end{array}$ & 101.77 & & \\
\hline
\end{tabular}

*SDP $=$ social distancing practices

The previous table indicated that the MannWhitney $U$ test revealed no significant difference between Hurghada and Sharm El-Sheikh five-star hotels in terms of social distancing practices applied at the 5-star hotels during COVID-19 pandemic, where sig. value for all practices was more than 0.05 (see Table 22). Meanwhile, the previous finding concluded the similarity in the practices followed at the five-star hotels in Hurghada and Sharm El-Sheikh cities during the coronavirus (COVID-19). This result was answered the sixth question of this research.

\section{Conclusion}

This study aimed at exploring the procedures applied in 5-star hotels to deal with coronavirus (COVID-19) pandemic and to analyze the gap between actual and targeted practices to understand the perception of customers and managers towards precautionary measures at 5-star hotels. A questionnaire was carried out covering a sample of 5-star hotel managers (49) and customers (155) at Hurghada and Sharm El-Sheikh cities. To answer the research questions mean, standard deviation, Mann-Whitney U, and one sample T-tests were used. The main results of the research were, there were statistical significant differences between the opinions of managers and customers in terms of procedures of adjusting hotel operations followed by the 5 -star hotel managers during the coronavirus (COVID-19) pandemic, there are significant differences between the procedures of adjusting hotel operations followed by the 5-star hotel managers during COVID-19 and the standard level, There are significant differences between managers and customers in the five-star hotels in terms of offers of food and beverages provided during COVID-19 pandemic, there is a high level of managers' interest in commitment to food and beverage offers during COVID-19 pandemic that reach consumer satisfaction, there are significant differences between the offers of food and beverages provided by the 5 -star hotel managers during COVID-19 and the standard level, there are significant differences between the level of cleaning and disinfection practices followed at the 5-star hotel managers during COVID-19 and the standard level, and there are significant differences between the level of social distancing practices followed at the 5-star hotel managers during the COVID-19 and the standard level.

\section{Research limitations and recommendation}

The existing research cannot asseverate to be quite decisive because it is restricted to the size of a sample of just two tourist cities of Egypt and only included a sample of 5-star hotels. This research was performed during the period from July 2020 to October 2020.

\section{Recommendations}

It is necessary to review the procedures of adjusting hotel operations followed by the 5-star hotel managers during the coronavirus (COVID-19) pandemic periodically, to achieve customer satisfaction.

Hospitality managers; especially in five-star hotels, should be fully aware of the procedures of cleaning and disinfection applied during the coronavirus (COVID-19) pandemic to achieve customer satisfaction.

Hospitality managers: especially in the five-star hotels, should be fully aware of the procedures of social distancing practices followed at the 5-star hotel managers during the coronavirus (COVID19)

It is necessary to develop food and beverage offers and use them as a competitive advantage during the coronavirus (COVID-19).

The commitment of the hotel establishments to the safe distances in the places of residence of the workers, and to provide areas to isolate the infected 
cases when they appear (simple and medium-risk cases only).

Educating employees about all information related to the emerging corona virus, introducing them to the symptoms of the disease and all preventive measures that must be followed to prevent infection among them, and the need to notify the facility management of the appearance of any symptoms on any of them, or on any of the visitors and residents

\section{References}

Abd El-Aziz, T. M. and Stockanda, J. D. (2020), “Recent against COVID-19 coronavirus (SARS-CoV-2) - an update on the status', journal of Infection, Genetics and Evolution, Vol. 83, 104327. Available at: https://www.sciencedirect.com/science/article/abs/ pii/S1567134820301581. (last accessed 15/8/2020) progress and challenges in drug development

at: https://www.alroeya.com/117-53/2135792-6\%D9\%85\%D9\%84\%D9\%8A\%D8\%A7\%D8\%B1 \%D8\%A7\%D8\%AA\%D8\%AF\%D9\%88\%D9\%84 \%D8\%A7\%D8\%B1\%D8\%AE\%D8\%B3\%D8\%A7 \%D8\%A6\%D8\%B1\%D9\%82\%D8\%B7\%D8\%A7 \%D8\%B9\%D8\%A7\%D9\%84\%D8\%B3\%D9\%8A \%D8\%A7\%D8\%AD\%D8\%A9\%D8\%A7\%D9\%84 \%D9\%85\%D8\%B5\%D8\%B1\%D9\%8A\%D8\%A8 \%D8\%B3\%D8\%A8\%D8\%A8-

\%D9\%83\%D9\%88\%D8\%B1\%D9\%88\%D9\%86\% D8\%A7 (last accessed 12/11/2020)

Bhattarai A., Long, H. and Siegel, R. (2020) "The first US layoffs from the coronavirus are here. Stars and Stripes". Available at: https://www.stripes.com/news/us/the-first-uslayoffs-from-the-coronavirus-are-here-1.622069. (last accessed 2/9/2020)

Buck, M. Arnold, G. Chazan, C. Cookson, (2020), "Coronavirus declared a pandemic as fears of Ajay, S.S., and Micah, B.M., (2014) " Sampling Techniques deconomic crisis mount". Available at: Determination of Sample Size Applied Statistics Research: Ahttps://www.ft.com/content/d72f1e54-6396-11eaOverview", International Journal of Economics, Commercb3f3-fe4680ea68b5. (last accessed 20/8/2020) and Management, Vol.11, pp. 1-22.

Akhbarelyom (2020), "In numbers and statistics, the impact of Corona on the travel and tourism industry in 2020", Available at: https://akhbarelyom.com/news/newdetails/3045784 11/\%D8\%A8\%D8\%A7\%D9\%84\%D8\%A3\%D8\% B1\%D9\%82\%D8\%A7\%D9\%85\%D9\%88\%D8\%A 7\%D9\%84\%D8\%A5\%D8\%AD\%D8\%B5\%D8\%A 7\%D8\%A6\%D9\%8A\%D8\%A7\%D8\%AA..\%D8\% AA\%D8\%A3\%D8\%AB\%D9\%8A\%D8\%B1\%D9 \%83\%D9\%88\%D8\%B1\%D9\%88\%D9\%86\%D8\% A7\%D8\%B9\%D9\%84\%D9\%89\%D8\%B5\%D9\%8 6\%D8\%A7\%D8\%B9\%D8\%A9\%D8\%A7\%D9\%8 4\%D8\%B3\%D9\%81\%D8\%B1\%D9\%88\%D8\%A7 \%D9\%84\%D8\%B3\%D9\%8A\%D8\%A7\%D8\%AD \%D8\%A9-\%D8\%B9\%D8\%A7\%D9\%85-2020 (last accessed 10/11/2020)

Alarabiya (2020), Because of Corona ... New regulations for residency in hotels in Egypt, Available at https://www.alarabiya.net/ar/aswaq/travel-andtourism/2020/05/03/\%D8\%A8\%D8\%B3\%D8\%A8 \%D8\%A8\%D9\%83\%D9\%88\%D8\%B1\%D9\%88\% D9\%86\%D8\%A7\%D8\%B6\%D9\%88\%D8\%A7\% D8\%A8\%D8\%B7\%D8\%AC\%D8\%AF\%D9\%8A\%D8\%AF\%D8\%A $\underline{9}$ \%D9\%84\%D9\%84\%D8\%A7\%D9\%82\%D8\%A7 \%D9\%85\%D8\%A9\%D8 A8\%D9\%81\%D9\%86\%D8\%A7\%D8\%AF\%D9\%8 2\%D9\%85\%D8\%B5\%D8\%B1- _last accessed $10 / 11 / 2020)$

Alborsaanews, (2020), "The effects of "Corona" appear on Egyptian hotel reservations" available at: https://alborsaanews.com/2020/03/04/1303822

Alroeya (2020), "6 billion dollars in losses to the Egyptian tourism sector due to Corona", Available
Egypt hotel guide, 2016. Ministry of Tourism, Information Center.

El-Erian, M. (2020), "The Coming Coronavirus Recession and the Uncharted Territory Beyond. Foreign Affairs, Media Report". Available at: https://www.foreignaffairs.com/articles/2020-0317/coming-coronavirus-recession. (last accessed $3 / 8 / 2020)$

Esposito, A. (2020), "The Worst Hit Equity Sectors in 2020". Morningstar. Available at: https://www.morningstar.co.uk/uk/news/200469/th e-worst-hit-equity-sectors-in-2020.aspx. (last accessed 10/9/2020)

Fabrigar, R.L., Wegener, W.T., MacCallum, C.R., and Strahan,J.E., (1999), "Evaluating the Use of Exploratory Factor Analysis in Psychological Research", Psychological Methods, Vol. 4,272-299.

Fernandes, N. (2020), "Economic effects of coronavirus outbreak (COVID-19) on the world economy", Available

at: https://papers.ssrn.com/sol3/papers.cfm?abstract_id $=3557504$. (last accessed 20/8/2020)

Gossling, S, Scott, D, Hall, M. (2021), "Pandemics, tourism and global change: a rapid assessment of COVID-19", Journal of Sustainable Tourism, Volume 29, Issue 1, Available at: https://www.tandfonline.com/doi/full/10.1080/096 69582.2020.1758708. (last accessed 15/12/2021)

Guidance on Preparing Workplaces for COVID-19, (2020), "Personal Protective Equipment (PPE)", Available at: https://www.osha.gov/Publications/OSHA3990.pdf (last accessed 3/1/2020)

Henson, R.K., (2001), "Understanding Internal Consistency Reliability Estimates: A Conceptual Primer on Coefficient Alpha", Measurement and 
valuation in Counseling and Development, Vol. 34,177-188.

Hoque, A, Afrin, F. S, Waliul, M. H, Arif, I, Abdul Hamid, A. B. (2020), "The Effect of Coronavirus (COVID-19) in the Tourism Industry in China", Asian Journal of Multidisciplinary Studies, Vol. 3, No. $1 . \quad$ Available at: https://asianjournal.org/online/index.php/ajms/artic le/view/213. (last accessed 15/12/2020)

Jennings, R. (2020), “'Unprecedented' Lockdown of Manila Expected to Cut Philippine Economic Growth". The News Lens. Available at: https://international.thenewslens.com/article/13257 2. (last accessed $2 / 8 / 2020$ )

Laing, T. (2020), "The economic impact of the Coronavirus 2019 (Covid-2019): Implications for the mining industry", The Extractive Industries and Society, Vol.7, Issue 8, 580-582. Available at: https://www.sciencedirect.com/science/article/abs/ pii/S2214790X2030126X. (last accessed $15 / 12 / 2020)$

Larry Elliot, L. (2020), "Prepare for the coronavirus global recession. The Guardian. Media report. Available

at: https://www.theguardian.com/business/2020/mar/1 5/prepare-for-the-coronavirus-global-recession. (last accessed 16/9/2020)

Li, H, Xu, J, Cao, B. (2020), "Potential antiviral therapeutics for 2019 Novel coronavirus", Chinese Journal of Tuberculosis and Respiratory Diseases, Vol, 43, Issue 3, 170-172. Available at: https://europepmc.org/article/med/32023685. (last accessed 15/12/2020)

Lo, K. (2020), “Coronavirus: China says over 90 per cent of state firms back in business after manufacturing index hits all-time low". South China Morning Post. Available

at:

https://www.scmp.com/economy/chinaeconomy/article/3053073/coronavirus-china-says90-cent-state-firms-back-business. (last accessed $18 / 9 / 2020)$

Loeb, A. (2020), "Flattening the COVID-19 curves. Scientific American Blog Network", Available at: https://blogs.scientificamerican. com/observations/flattening-the-covid-19-curves/. (last accessed 15/8/2020)

Maria,S. I, Natale, F, Santamaria, C, Spyratos, S, Vespe, M. (2020), "Estimating and projecting air passenger traffic during the COVID-19 coronavirus outbreak and its socio-economic impact" European Commission, Safety Science 129, 104791. Available at: https://www.sciencedirect.com/science/article/pii/S 0925753520301880. (last accessed 15/12/2020)

Nicolaa, M, Alsafib, Z, Sohrabic, C, Kerwand, A, AlJabird, A, Iosifidisc, C, Aghae, M. and Aghaf, R. (2020), "The socio-economic implications of the coronavirus pandemic (COVID-19)", International Journal of Surgery 78, 185-193

Ozili, P. K. (2019), "100 Quotes from the Global Financial Crisis: Lessons for the future", Available at:

https://www.researchgate.net/publication/3378879 09_100_Quotes from the Global_Financial_Crisi s_Lessons for the future. (last accessed 5/8/2020)

Ozili, P. K. and Arun (2020), "Spillover of COVID-19: impact on the Global Economy", Available at: https://ssrn.com/abstract $=3562570$ (last accessed $\underline{11 / 9 / 2020)}$

Sabbah, M. Y. (2020), "The Novel Coronavirus Disease (COVID-19) Outbreak: The Israeli Experience, Journal of Medical Science, Vol. 89 No. 1, e413. Available at: https://jms.ump.edu.pl/index.php/JMS/article/view/ 413/469. (last accessed 15/12/2020)

Shkeeb, B. (2014)., A comparative analytical study of the formulas used in calculating the random sample size. Tishreen University Journal of Research and Scientific Studies, 97(5), 85-100.

Wang, L.S., Wang, Ye, D, Liu, Q. (2020), “A review of the 2019 Novel Coronavirus (COVID-19) based on current evidence", International Journal of Antimicrobial Agents. Volume 55, Issue

6, 105948. Available at: https://www.sciencedirect.com/science/article/abs/ pii/S0924857920300984. (last accessed $15 / 12 / 2020)$

WHO (2020), "Critical actions to prepare for and respond to COVID-19", Available at: https://www.who.int/ar/emergencies/diseases/novel coronavirus2019/technical-guidance (last accessed $\underline{12 / 12 / 2020)}$

Youm7 (2020), "How do hotels plan to work under Corona? Mandatory conditions that guarantee the safety of workers and guests. Sterilization of rooms daily and corridors every hour. One and a half meters the permissible distance for tables. The availability of medical teams. And the occupancy rate currently does not exceed 25\%" Available at: ,https://www.youm7.com/story/2020/4/28/\%D9\%8 3\%D9\%8A\%D9\%81-

\% $8 \%$ AA\%D8\%AE\%D8\%B7\%D8\%B7\%D8\%A 7\%D9\%84\%D9\%81\%D9\%86\%D8\%A7\%D8\%AF \%D9\%82\%D9\%84\%D9\%84\%D8\%B9\%D9\%85\% D9\%84\%D9\%81\%D9\%89\%D8\%B8\%D9\%84\%D 9\%83\%D9\%88\%D8\%B1\%D9\%88\%D9\%86\%D8 \%A7\% D8\%B4\%D8\%B1\%D9\%88\%D8\%B7\%D8 \% A5\%D9\%84\%D8\%B2\%D8\%A7\%D9\%85\%D9 \%8A\%D8\%A9\%D8\%AA\%D8\%B6\%D9\%85\%D9 $\% 86 / 4746458$ (last accessed 12/11/2020)

Youm7 (2020), "The Tourism Promotion Authority holds an urgent meeting to study the impact of the Coronavirus on the sector", Available at: https://www.youm7.com/story/2020/3/4/\%D9\%8 7\%D9\%8A\%D8\%A6\%D8\%A9\%D8\%AA\%D9\%86\%D8 
A. Rady and M. A. Atia / IJHTH vol 14 issue 2 (2020)112-128

\%B4\%D9\%8A\%D8\%B7\%D8\%A7\%D9\%84\%D8\%B3\% D9\%8A\%D8\%A7\%D8\%AD\%D8\%A9\%D8\%AA\%D8\%

B9\%D9\%82\%D8\%AF\%D8\%A7\%D8\%AC\%D8\%AA\%D

9\%85\%D8\%A7\%D8\%B9\%D8\%A7\%D8\%B9\%D8\%A7

\%D8\%AC\%D9\%84\%D8\%A7\%D9\%84\%D8\%AF\%D8\%

B1\%D8\%A7\%D8\%B3\%D8\%A9\%D8\%AA\%D8\%A3\%D
8\%AB\%D9\%8A\%D8\%B1\%D9\%81\%D9\%8A\%D8\%B1 $\% \mathrm{D} 9 \% 88 \% \mathrm{D} 8 \% \mathrm{~B} 3-$

\%D9\%83\%D9\%88\%D8\%B1\%D9\%88\%D9\%86\%D8\% A7/4656054 (last accessed 10/11/2020) 